\title{
Longitudinal evaluation of energy expenditure in preterm infants with birth weight less than $1000 \mathrm{~g}$
}

\author{
Jacqueline Bauer $^{1}{ }^{*}$, Kathrin Maier ${ }^{2}$, Gerald Hellstern ${ }^{1}$ and Otwin Linderkamp ${ }^{1}$ \\ ${ }^{1}$ Division of Neonatology, Department of Pediatrics, University of Heidelberg, Germany \\ ${ }^{2}$ Department of Paediatrics, University of Freiburg, Germany
}

(Received 9 May 2002 - Revised 1 November 2002 - Accepted 22 November 2002)

\begin{abstract}
The aim of the present study was to obtain serial values of $\mathrm{O}_{2}$ consumption $\left(V_{\mathrm{O}_{2}}\right), \mathrm{CO}_{2}$ production $\left(V_{\mathrm{CO}_{2}}\right)$ and energy expenditure (EE) in healthy but extremely-low-birth-weight infants (birth weight $<1000 \mathrm{~g}$ ), during the first 5 weeks after birth. A total of seventeen spontaneously breathing and appropriate-for-gestational-age (birth weight and body length above the 10th and below the 90th percentile) preterm infants with gestational age 25-28 weeks and birth weight 590$990 \mathrm{~g}$ were enrolled in the study. Calorimetry was performed using an open-circuit calorimeter on days $6,12,18,24,30$ and 36 of postnatal life. During the 5 weeks of observation, $V_{\mathrm{O}_{2}}$ increased from 4.7 (SD 0.5) to 9.1 (SD 1.0) $\mathrm{ml} / \mathrm{kg}$ per min, $V_{\mathrm{CO}_{2}}$ from 4.5 (SD 0.4) to 8.3 (SD 0.6) $\mathrm{ml} / \mathrm{kg}$ per min and EE from 115 (SD 12) to 310 (SD 71) $\mathrm{kJ} / \mathrm{kg}$ per d. The energy intake was always higher than EE, even at days 6 and 12. The RER decreased from 0.99 (SD 0.09) at day 12 to 0.91 (SD 0.05 ) at day 30. On all study days, there were highly significant positive correlations between energy intake and weight gain, EE and weight gain, and EE and energy intake $(P<0 \cdot 05)$. Multiple regression analysis showed that on most study days EE was more affected by energy intake than by weight gain. We conclude that in healthy preterm infants with birth weight $<1000$ g, EE increases by about $150 \%$ in the first 5 weeks after birth, and that the EE values are related to energy intake and weight gain independent of postnatal age.
\end{abstract}

Energy expenditure: Growth: Preterm: Oxygen consumption

The substantial improvement of the survival rate in extremely-low-birth-weight (ELBW) infants (birth weight $<1000 \mathrm{~g}$ ) has changed the focus towards prevention of long-term morbidity. Adequate nutrition is an important prerequisite for intact survival of ELBW infants (Lucas, 1987; Lucas et al. 2001). Determinations of energy requirements are usually based on calculation of the energy balance (= energy intake (EI) - energy loss via faeces and urine energy expenditure (EE)). Energy loss via faeces and urine is about $10 \% \mathrm{EI}$, independent of postnatal age and EI in preterm infants (Sauer et al. 1984a). However, EE tends to increase with increasing age. Chessex et al. (1981) suggested that EE increases with age of preterm infants due to increasing EI. Their assumption was based on only three serial studies in preterm infants with a mean birth weight of 1155 (SD 39) g. Leitch \& Denne (2000) summarised published EE values measured in seventy-five preterm infants with birth weight $<1000 \mathrm{~g} v$. postnatal age, and found an increase of EE from $209 \mathrm{~kJ} / \mathrm{kg}$ per d at birth to $272 \mathrm{~kJ} / \mathrm{kg}$ per d at 5 weeks of age. However, thirty-five of the seventy-five infants were small-for-gestational-age with a mean postnatal age of 6.0 weeks, whereas forty infants had birth weights appropriate for gestational age and mean postnatal age of 2.5 weeks. Thus, the apparent increase in EE with age may be due in part to higher EE of small-for-gestational-age infants (Boehler et al. 1999).

Recommendations for EI and dietary intakes are usually based on the assumption that postnatal growth should be similar to that in utero to achieve intrauterine growth rates. Preterm infants need an EI of $419-503 \mathrm{~kJ}$ (100-120 kcal)/kg per d (Cooke \& Embleton, 2000). However, preterm infants usually receive only about $100-120 \mathrm{~kJ} / \mathrm{kg}$ on the first day after birth. EI is then increased by about $35 \mathrm{~kJ} / \mathrm{kg}$ per $\mathrm{d}$ for $4-5$ weeks until the recommended EI is reached. Cooke \& Embleton (2000) calculated that 5 weeks after birth, ELBW infants have a cumulative deficit of energy of $3349 \mathrm{~kJ}(800 \mathrm{kcal}) /$ $\mathrm{kg}$. Reasons for this severe undernutrition include medical complications, assumed and actual feeding intolerance and concerns about necrotising enterocolitis.

\footnotetext{
Abbreviations: EE, energy expenditure; EI, energy intake; ELBW, extremely-low-birth-weight; $V_{\mathrm{CO}_{2}}$, carbon dioxide production; $V_{\mathrm{O}_{2}}$, oxygen consumption. * Corresponding author: Dr Jacqueline Bauer, fax +49 6221 565602, email Jacqueline_Bauer@med.uni-heidelberg.de
} 
No study on serial determinations of EE in ELBW infants has been found in the literature. The aim of our present study was to obtain serial values for EE in healthy preterm infants with birth weight $<1000 \mathrm{~g}$, by measuring $\mathrm{O}_{2}$ consumption $\left(V_{\mathrm{O}_{2}}\right)$ and $\mathrm{CO}_{2}$ production $\left(V_{\mathrm{CO}_{2}}\right)$ by indirect calorimetry.

\section{Patients and methods}

Seventeen spontaneously breathing preterm infants with mean gestational age of 26.6 (SD 1) (range 25-28, median value 27.0) weeks and mean birth weight of 836 (SD 101) (range 590-990, median value 820) g were enrolled in the study. Informed consent was obtained from the parents of each infant studied. The study had been approved by the Ethics Committee of the University of Heidelberg Medical Centre. Infants were free of major malformations, septicaemia, and pulmonary or circulatory compromise, and did not receive supplemental $\mathrm{O}_{2}$ during the study period. Because infants with intrauterine growth retardation may show increased EE (Picaud et al. 1994; Boehler et al. 1999), only appropriate-for-gestational-age infants (10th to 90th birth-weight percentile according to Munich growth charts; Riegel \& Linderkamp, 1991) were included. Infants with hyperirritability were excluded, since EE increases with increasing physical activity (Billeaud et al. 1993). All infants were treated with caffeine for apnoea (Bauer et al. 2001). Serum concentrations of caffeine ranged from 10 to $15 \mu \mathrm{g} / \mathrm{ml}$. No other stimulatory drugs were given during the study period. None of the infants received sedative or analgesic drugs.

\section{Nutrition and body weight}

Parenteral nutrition (glucose, amino acids and electrolytes) was started immediately after birth. Gastric nutrition (small amounts of preterm formula milk) was started on the first day of birth. On the first study day (day 6), infants received approximately $50 \%$ total EI parenterally and $50 \%$ enterally via a gastric tube. At $12-36 \mathrm{~d}$, all infants were fed preterm formula milk exclusively. The preterm formula milk was given every $2 \mathrm{~h}$ via gastric tubes as a bolus. The formula contained $24 \mathrm{~g}$ protein, $78 \mathrm{~g}$ carbohydrate, $44 \mathrm{~g}$ fat and $3350 \mathrm{~kJ} /$ litre (Prematil ${ }^{\circledR}$; Milupa, Friedrichsdorf, Germany). The same formula was used in all infants. Body weight was measured daily at 08.00 hours using a calibrated electronic scale with a resolution of $1 \mathrm{~g}$. The weight gain was calculated as the mean value from six consecutive days around the calorimetric measurements (e.g. calorimetry at day 12, weight gain from day 10 to 15). The modified Atwater factor (Livesey, 2001) was used to estimate the energy content.

\section{Monitoring and behavioural state}

Heart rate, respiratory rate and $\mathrm{O}_{2}$ saturation were monitored continuously. Skin (lower leg) and rectal temperatures (Exacon 4000; Exacon, Roskilde, Denmark) were measured continuously for $2 \mathrm{~h}$ before, during and after indirect calorimetry. Skin temperature was kept constant at $34 \cdot 5-35 \cdot 8^{\circ} \mathrm{C}$ and rectal temperature was $36 \cdot 5-37 \cdot 5^{\circ} \mathrm{C}$.
All infants were studied only during sleep (according to Freymond et al. 1986).

\section{Indirect calorimetry}

In seventeen infants, measurements of $V_{\mathrm{O}_{2}}$ and $V_{\mathrm{CO}_{2}}$ were performed by means of a portable open-circuit continuous indirect calorimetry device, the Deltatrac II Metabolic Monitor (Datex-Ohmeda, Instrumentarium Corp., Helsinki, Finland). Details of the technique, the precision of the $V_{\mathrm{O}_{2}}$ measurement device and its validation for indirect calorimetry in neonates were as previously described (Bauer et al. 1996, 2002). The accuracy of the device was tested as a mean experimental error for $V_{\mathrm{O}_{2}}$ measurements of 2 (SD 2) \% (Bauer et al. 1997). This transportable device consists of a fast differential paramagnetic $\mathrm{O}_{2}$ sensor and an infrared $\mathrm{CO}_{2}$ sensor attached to a silicon face mask that was continuously ventilated by a constant-flow generator. The device does not measure inspiratory and expiratory $\mathrm{O}_{2}$ concentration separately, but measures $\mathrm{O}_{2}$ differences of $0.1 \mathrm{ml} / \mathrm{l}$ as a $1 \mathrm{~min}$ average very accurately. Calibration of the device was performed before each measurement with a standard calibration gas $\left(\mathrm{O}_{2}-\mathrm{CO}_{2}, 5: 95\right)$. The analyser was set at zero according to room air. Calibration gases were prepared to an accuracy of $\pm 0.03 \%$ and certified gravimetrically. A silicon face mask and a sampling flow of 3 litres/min were used. The Deltatrac II monitor stores each minute-to-minute value of $V_{\mathrm{O}_{2}}$ and $V_{\mathrm{CO}_{2}}$ electronically. At the end of the measurements the values were transmitted to a personal computer and processed using SAS for Windows (SAS Institute Inc., Cary, NC, USA). The non-protein EE was calculated as: $\mathrm{EE}(\mathrm{kJ} / \mathrm{kg}$ per d $)=5.50 V_{\mathrm{O}_{2}}(\mathrm{~kJ} / \mathrm{kg}$ per d $)+1.76 V_{\mathrm{CO}_{2}}(\mathrm{~kJ} / \mathrm{kg}$ per d $)$ (Weir, 1949). Marks et al. (1987) and Bauer et al. (1997, 1998) showed that a face mask gives more reliable results in very-low-birth-weight infants $(<1500 \mathrm{~g})$ than a hood, and offers the advantage of ready access to the infant. Errors in $V_{\mathrm{O}_{2}}$ and $V_{\mathrm{CO}_{2}}$ measurements may result from incomplete breath sampling, inaccurate flow measurement and rapid changes of physiological variables such as increasing activity or changing body temperature. The relatively low flow rate of 3 litres/min used in our present study, and in those of other authors, on preterm infants has been shown to be accurate up to a tidal volume of $15 \mathrm{ml}$ (Bauer et al. 1997, 1998). The flow is accurately delivered by the device (Perring et al. 2000). Infants in our present study were continuously observed by the principal investigator (J. B.). Rectal and skin temperature remained constant throughout each study period. The five-minute-to-five-minute variability of the $V_{\mathrm{O}_{2}}$ and $V_{\mathrm{CO}_{2}}$ measurements was studied in ten preterm infants during one study period. Variability averaged 1.2 (SD 0.7) $\%$.

\section{Study protocol}

If inclusion criteria were fulfilled, measurements of $V_{\mathrm{O}_{2}}$ and $V_{\mathrm{CO}_{2}}$ were started on day 6 of postnatal life. The measurements were repeated in all seventeen infants on days $12,18,24,30$ and 36. Calorimetry was started at 15.00 to 16.00 hours and lasted for $4 \mathrm{~h}$. Because $V_{\mathrm{O}_{2}}$ and $V_{\mathrm{CO}_{2}}$ are strongly influenced by feeding, each period of 
indirect calorimetry began 45 min after feeding, according to published recommendations (Stothers \& Warner, 1979). Measurements were started after an equilibration time of $15 \mathrm{~min}$ as described by the manufacturer. Therefore, each period of calorimetry began $60 \mathrm{~min}$ after feeding and lasted for $60 \mathrm{~min}$ to minimise effects of postprandial thermogenesis on the results. Four periods of measurements were done to obtain $4 \mathrm{~h}$ of calorimetry. The four mean values of $V_{\mathrm{O}_{2}}$ and $V_{\mathrm{CO}_{2}}$ were used for calculation of individual $\mathrm{EE}$ values. Measurements were not interrupted by nursing routine. Indirect calorimetry and temperature measurements were done in a double-walled, air temperature-controlled incubator (model 8000; Draeger AG, Lübeck, Germany) at thermoneutral temperatures (31$37^{\circ} \mathrm{C}$ ) and humidity of $60-75 \%$, in accordance with the recommendations of Sauer et al. $(1984 a, b)$. All infants were treated in the same type of incubator.

\section{Results}

The values of $V_{\mathrm{O}_{2}}$ and $V_{\mathrm{CO}_{2}}$ increased 2.0-fold, and EE 2.5fold, during the observation period of 5 weeks (Tables 1 and 2). EI was always greater than EE and reached a maximum value of $495 \mathrm{~kJ} / \mathrm{kg}$ per d on day 36. Due to an early loss of $10 \%$ body weight, the mean weight gain was negative during the first week of birth. Birth weight was regained during the second or third week, at a mean value of $14 \mathrm{~d}$ after birth.

On each study day there were highly significant correlations between EE and EI, EE and weight gain, and EI and weight gain (Table $3 ; P<0 \cdot 001$ ).

The correlation coefficients indicate that both EI and weight gain increased EE. To assess the relative contributions of EI and weight gain, multiple regression analysis, using EE as dependent variable and EI and weight gain as independent variables, was done separately for each study day from day 12 to 36 . On days 12,18 and 30, EI contributed about two-thirds and body weight one-third to each unit increase of EE. At day 24, only EI contributed significantly $(P<0 \cdot 05)$, and at day 36 only weight gain contributed to increases in EE.

\section{Discussion}

Our present investigation was designed to study the effect of postnatal age on EE in ELBW infants during the first
5 weeks after birth. Serial studies on EE and other nutritional results have not been published previously for ELBW infants with birth weight $<1000$ g. Leitch \& Denne (2000) summarised results from twelve reports on $\mathrm{EE}$ in ELBW infants and calculated a rise of $\mathrm{EE}$ from $209 \mathrm{~kJ} / \mathrm{kg}$ per $\mathrm{d}$ during the initial days to $272 \mathrm{~kJ} / \mathrm{kg}$ per $\mathrm{d}$ at 5 weeks of postnatal age. Gudinchet et al. (1982) studied $\mathrm{EE}$ in three infants with birth weight $<1000 \mathrm{~g}$. Two were studied at 1 and 4 weeks of age and one infant was studied at 2, 3, 5 and 6 weeks of age. At 1 week of age, EE averaged $163 \mathrm{~kJ} / \mathrm{kg}$ and at 4 weeks $253 \mathrm{~kJ} / \mathrm{kg}$. We found a much more pronounced rise of EE from $115(\mathrm{SD} 12) \mathrm{kJ} /$ $\mathrm{kg}$ per d at day 6 to 310 (SD 71) $\mathrm{kJ} / \mathrm{kg}$ per d at day 36 (Table 2). The greater initial values measured in previous studies may be explained by the inclusion of infants with severe respiratory disease and mechanical ventilation (Wahlig et al. 1994), whereas the infants in the present study were free of respiratory and other complications. Moreover, our present infants were nursed in doublewalled incubators to minimise heat loss, whereas some of the previous investigators used open incubators, thereby increasing the heat loss greatly (Sauer et al. 1984b). In the study of Gudinchet et al. (1982), EI at 1 week of age averaged $299 \mathrm{~kJ} / \mathrm{kg}$ per d. The higher EI may have increased $\mathrm{EE}$ in their infants.

We found a positive energy balance during the entire observation period. In two previous studies on EI and EE in ELBW infants with postnatal age $<7 \mathrm{~d}$, EI was only 126 and $155 \mathrm{~kJ} / \mathrm{kg}$ per $\mathrm{d}$ and the EE was 205 and $230 \mathrm{~kJ} /$ $\mathrm{kg}$ per $\mathrm{d}$, thus resulting in a highly negative energy balance (Samiec et al. 1994; Wahlig et al. 1994). Gudinchet et al. (1982) found a positive energy balance in two preterm infants with birth weight $<1000 \mathrm{~g}$ of $140 \mathrm{~kJ} / \mathrm{kg}$ at $7 \mathrm{~d}$ of age. Infants in their study were without major medical problems, as in our present study.

We found highly significant relationships between EE and EI and between EE and weight gain at each study day. The results of multivariant analysis showed that EI had a stronger effect on EE than weight gain on most study days. This suggests that the increase in EE with postnatal age is not causally related to increasing age, but due to the increase in EI and weight gain.

From their overall relationship between EE and weight gain, Chessex et al. (1981) calculated a minimum EE (without weight gain) of $232 \mathrm{~kJ} / \mathrm{kg}$ per $\mathrm{d}$. The minimum $\mathrm{EE}$ in our present infants was much less, in particular

Table 1. Serial values of body weight, body length, oxygen consumption $\left(V_{\mathrm{O}_{2}}\right)$, carbon dioxide production $\left(V_{\mathrm{CO}_{2}}\right)$ and $\mathrm{RER}$ in preterm infants*

(Mean values and standard deviations for seventeen infants)

\begin{tabular}{|c|c|c|c|c|c|c|c|c|c|c|}
\hline \multirow[b]{2}{*}{ Postnatal age (d) } & \multicolumn{2}{|c|}{ Body weight (g) } & \multicolumn{2}{|c|}{ Body length (m) } & \multicolumn{2}{|c|}{$\begin{array}{c}V_{\mathrm{O}_{2}}(\mathrm{ml} / \mathrm{kg} \text { per } \\
\mathrm{min})\end{array}$} & \multicolumn{2}{|c|}{$\begin{array}{c}V_{\mathrm{CO}_{2}}(\mathrm{ml} / \mathrm{kg} \\
\text { per min) }\end{array}$} & \multicolumn{2}{|c|}{ RER } \\
\hline & Mean & $\overline{\mathrm{SD}}$ & Mean & SD & Mean & $\mathrm{SD}$ & Mean & SD & Mean & SD \\
\hline 6 & 780 & 99 & 0.34 & 0.013 & $4 \cdot 7$ & 0.5 & 4.5 & 0.4 & 0.95 & 0.05 \\
\hline 12 & 819 & 204 & 0.34 & 0.012 & $5 \cdot 6$ & 0.5 & $5 \cdot 6$ & 0.5 & 0.99 & 0.09 \\
\hline 18 & 871 & 101 & 0.35 & 0.015 & $7 \cdot 0$ & 0.3 & 6.9 & 0.4 & 0.98 & 0.03 \\
\hline 24 & 956 & 103 & 0.36 & 0.015 & $7 \cdot 6$ & 0.6 & $7 \cdot 3$ & 0.5 & 0.98 & 0.05 \\
\hline 30 & 1036 & 106 & 0.37 & 0.023 & $8 \cdot 8$ & 0.6 & 8.0 & 0.3 & 0.91 & 0.05 \\
\hline 36 & 1149 & 105 & 0.39 & 0.019 & $9 \cdot 1$ & $1 \cdot 0$ & $8 \cdot 3$ & 0.6 & 0.91 & 0.04 \\
\hline
\end{tabular}

${ }^{*}$ For details of subjects and procedures, see p. 534. 
Table 2. Serial values of energy balance and daily weight-gain values in preterm infants* (Mean values and standard deviations for seventeen infants)

\begin{tabular}{|c|c|c|c|c|c|c|}
\hline \multirow[b]{2}{*}{ Postnatal age (d) } & \multicolumn{2}{|c|}{$\begin{array}{l}\text { Energy intake } \\
(\mathrm{kJ} / \mathrm{kg} \text { per } \mathrm{d})\end{array}$} & \multicolumn{2}{|c|}{$\begin{array}{l}\text { Energy expenditure } \\
(\mathrm{kJ} / \mathrm{kg} \text { per } \mathrm{d})\end{array}$} & \multicolumn{2}{|c|}{$\begin{array}{l}\text { Weight gain } \\
\text { (g/kg per d) }\end{array}$} \\
\hline & Mean & $\overline{S D}$ & Mean & $\overline{\mathrm{SD}}$ & Mean & $\overline{S D}$ \\
\hline 6 & 222 & 27 & 115 & 12 & -11 & 5 \\
\hline 12 & 299 & 35 & 132 & 23 & 9 & 5 \\
\hline 18 & 338 & 57 & 175 & 28 & 11 & 3 \\
\hline 24 & 375 & 40 & 206 & 33 & 16 & 3 \\
\hline 30 & 485 & 60 & 277 & 41 & 17 & 5 \\
\hline 36 & 495 & 91 & 310 & 71 & 19 & 9 \\
\hline
\end{tabular}

${ }^{\star}$ For details of subjects and procedures, see p. 534.

Table 3. Relationships between energy expenditure, energy intake and weight gain in preterm infants* (Correlation coefficients for seventeen infants)

\begin{tabular}{|c|c|c|c|c|c|c|}
\hline \multirow[b]{2}{*}{ Age (d) } & \multicolumn{2}{|l|}{ EE $v$. El† } & \multicolumn{2}{|l|}{ EE $v$. WG $†$} & \multicolumn{2}{|l|}{ El v. WG } \\
\hline & Regression equation & $r^{2}$ & Regression equation & $r^{2}$ & Regression equation & $r^{2}$ \\
\hline 6 & $E E=0 \cdot 38 E I+10 \cdot 51$ & 0.77 & - & & - & \\
\hline 12 & $\mathrm{EE}=0.45 \mathrm{El}+3.06$ & 0.78 & $E E=10.51 W G+39.1$ & 0.79 & $\mathrm{El}=22 \cdot 97 \mathrm{WG}+113 \cdot 3$ & 0.90 \\
\hline 18 & $\mathrm{EE}=0 \cdot 47 \mathrm{El}+15 \cdot 21$ & 0.93 & $\mathrm{EE}=10 \cdot 26 \mathrm{WG}+67.2$ & 0.92 & $\mathrm{EI}=21.03 W \mathrm{~W}+121.67$ & 0.91 \\
\hline 24 & $E E=0.78 E I-92.14$ & 0.88 & $E E=8 \cdot 84 W G+67.4$ & 0.76 & $E \mathrm{I}=10.77 \mathrm{WG}+211.29$ & 0.78 \\
\hline 30 & $\mathrm{EE}=0.64 \mathrm{EI}-37.79$ & 0.88 & $\mathrm{EE}=7.75 W \mathrm{~W}+149.5$ & 0.90 & $\mathrm{El}=9.76 \mathrm{WG}+328.86$ & 0.68 \\
\hline 36 & $\mathrm{EE}=0.73 \mathrm{EI}-56 \cdot 10$ & 0.88 & $\mathrm{EE}=7 \cdot 75 \mathrm{WG}+157.7$ & 0.95 & $\mathrm{El}=9 \cdot 85 \mathrm{WG}+309 \cdot 28$ & 0.91 \\
\hline
\end{tabular}

$E E$, energy expenditure, El, energy intake; WG, weight gain.

${ }^{*}$ For details of subjects and procedures, see p. 534.

†EE was expressed as $\mathrm{kJ} / \mathrm{kg}$ per $\mathrm{d}$, El as $\mathrm{kJ} / \mathrm{kg}$ per $\mathrm{d}$ and $\mathrm{WG}$ as $\mathrm{g} / \mathrm{kg}$ per $\mathrm{d}$.

during the first $18 \mathrm{~d}$ after birth $(39 \cdot 1-67.4 \mathrm{~kJ} / \mathrm{kg}$ per d), but increased to $149.5 \mathrm{~kJ} / \mathrm{kg}$ per d on day 30 (Table 3). Chessex et al. (1981) do not report whether the infants in their study suffered from respiratory distress or whether they were nursed in closed or open incubators.

EE per $\mathrm{g}$ weight gain, calculated from regression analysis, decreased from $10.5 \mathrm{~kJ} / \mathrm{kg}$ per d at day 12 to $7.8 \mathrm{~kJ} / \mathrm{kg}$ per $\mathrm{d}$ at days 30 and 36 . From the regression equation $\mathrm{EI}=$ weight gain $\times \mathrm{b}+\mathrm{a}$, the minimum $\mathrm{EI}$ without weight gain (a) and the EI per g weight gain (b) can be calculated. This minimum EI increased from $113.3 \mathrm{~kJ} / \mathrm{kg}$ per d at day 12 to $319 \cdot 1 \mathrm{~kJ} / \mathrm{kg}$ per d at days 30 and 36 . The EI per g weight gain decreased from $21.5 \mathrm{~kJ} / \mathrm{g}$ at day 12 and $18 \cdot 0-10 \cdot 1 \mathrm{~kJ} / \mathrm{g}$ at days 24,30 and 36 .

Energy stored per g body weight can be calculated from measurements of EI, EE, energy loss via faeces and urine, and weight gain. From results in the literature on preterm infants with birth weight $<1000 \mathrm{~g}$, reviewed by Leitch \& Denne (2000), values ranging from 5.4 to $18.4 \mathrm{~kJ} / \mathrm{g}$ can be calculated. The wide range of energy storage per $g$ weight gain may be explained by a wide variation in the composition of newly formed tissue. Towers et al. (1999) studied the effects of various protein and energy contents of enteral feeds on EE and the energy expended in the deposition of fat and protein in preterm infants (mean gestational age 31 weeks and mean postnatal age $29 \mathrm{~d}$ ). Energy storage per $\mathrm{g}$ weight gain calculated from their results ranged from 9.2 to $16.3 \mathrm{~kJ} / \mathrm{g}$ and correlated with the fat:protein ratio deposited in new tissue. From the differences of EI and EE values divided by weight gain (Table 2), values of energy storage per $\mathrm{g}$ weight gain can be calculated. Values were 18.6, 14.8, 10.6, $12 \cdot 2$ and $9.7 \mathrm{~kJ} / \mathrm{g}$ on days $12,18,24,30$ and 36 of postnatal age respectively. A postnatal decrease in energy storage per $\mathrm{g}$ weight gain can also be derived from results in literature reviewed by Leitch \& Denne (2000). A postnatal decrease in the energy storage per $\mathrm{g}$ weight gain could be explained by decreasing fat:protein ratio in newly formed tissues, since the energy value of fat $(38.75 \mathrm{~kJ} / \mathrm{g})$ is greater than that of protein $(23.67 \mathrm{~kJ} / \mathrm{g}$ ) (Ziegler et al. 1976).

We conclude that extremely small but healthy preterm infants expend relatively little energy during the first 2 weeks after birth. They increase their EE during the first weeks of postnatal age by $150 \%$, due to rising EI and weight gain. The evidence suggests that the energy stored per $\mathrm{g}$ weight gain decreases during the first 3 weeks due to decreasing fat:protein ratios in new tissue. Longitudinal measurements of energy, protein and fat intakes, losses via faeces and urine, EE and weight gain in healthy extremely small preterm infants are necessary to assess this further.

\section{References}

Bauer J, Hentschel R \& Linderkamp O (2002) Effect of sepsis syndrome on neonatal oxygen consumption and energy expenditure. Pediatrics 110, e68.

Bauer J, Maier K, Linderkamp O \& Hentschel R (2001) Effect of caffeine on oxygen consumption and metabolic rate in very low birth weight infants with idiopathic apnea. Pediatrics 107, 660-663.

Bauer J, Sontheimer D, Fischer Ch \& Linderkamp O (1996) Metabolic rate and energy balance in very low birth weight 
infants during kangaroo holding by their mothers and fathers. Journal of Pediatrics 129, 608-611.

Bauer K, Pasel K, Uhrug C, Sperling P \& Versmold H (1997) Comparison of face mask, head hood, and canopy for breath sampling in flow-through indirect calorimetry to measure oxygen consumption and carbon dioxide production of preterm infants $<1500$ grams. Pediatric Research 41, 139-144.

Bauer K, Pyper A, Sperling P, Uhrig C \& Versmold H (1998) Effects of gestational and postnatal age on body temperature, oxygen consumption, and activity during early skin-to-skin contact between preterm infants of 25-30-week gestation and their mothers. Pediatric Research 44, 247-251.

Billeaud C, Piedboeuf B, Jequier JC \& Chessex P (1993) Relative contribution of physical activity to neonatal oxygen consumption. Early Human Development 32, 113-120.

Boehler T, Kaemer T, Janecke AR, Hoffmann GF \& Linderkamp O (1999) Increased energy expenditure and faecal fat excretion do not impair weight gain in small-for-gestational-age preterm infants. Early Human Development 54, 223-234.

Chessex P, Reichman BL, Verellen GJE, Putet G, Smith JM, Heim T \& Swyer P (1981) Influence of postnatal age, energy intake and weight gain on energy metabolism in the verylow-birth weight infant. Journal of Pediatrics 99, 761-766.

Cooke RJ \& Embleton ND (2000) Feeding issues in preterm infants. Archives of Disease in Childhood 83, F215-F218.

Freymond D, Schutz Y, Decombaz J, Micheli J-L \& Jequier E (1986) Energy balance, physical activity, and thermogenic effect of feeding in premature infants. Pediatric Research 20, 503-508.

Gudinchet F, Schutz Y, Micheli JL, Stettler E \& Jequier E (1982) Metabolic cost of growth in very low-birth-weight infants. Pediatric Research 16, 1025-1030.

Leitch CA \& Denne SC (2000) Energy expenditure in extremely low-birth weight infants. Clinics in Perinatology 27, 181-194.

Livesey G (2001) A perspective on food energy standards for nutrition labelling. British Journal of Nutrition 85, 271-287.

Lucas A (1987) Does diet in preterm infants influence clinical outcome? Biology of the Neonate 52, 141-146.

Lucas A, Fewtrell MS, Morley R, Singhal A, Abbott RA, Stephenson T, MacFadyen UM \& Clemens H (2001) Randomized trial of nutrient-enriched formula versus standard formula for postdischarge preterm infants. Pediatrics 108, 703-711.
Marks KH, Coen P, Kerrigan JR, Francalancia NA, Nardis EE \& Snider MT (1987) The accuracy and precision of an open-circuit system to measure oxygen consumption and carbon dioxide production in neonates. Pediatric Research 21, 58-65.

Perring J, Henderson M \& Cooke R (2000) Factors affecting the measurements of energy expenditure during energy balance studies in preterm infants. Pediatric Research 48, 518-523.

Picaud J-C, Putet G, Salle BL \& Senterre J (1994) Metabolic and energy balance in small- and appropriate-for-gestational-age, very low-birth-weight infants. Acta Paediatrica Supplemental 405, 54-59.

Riegel K \& Linderkamp O (1991) Das Neugeborene (The Neonate). In Lehrbuch der Kinderheilkunde (Textbook of Paediatrics), pp. 159-170 [K Betke, W Kürzer and J Schaub, editors]. Stuttgart: Keller/Wiskott.

Samiec TD, Radmacher P, Hill T \& Adamkin DH (1994) Measured energy expenditure in mechanically ventilated very low birth weight infants. American Journal of Medical Sciences 307, 182-184.

Sauer PJJ, Dane HJ \& Visser HKA (1984a) New standards for neutral thermal environment of healthy very low birth weight infants in week one of life. Archives of Disease in Childhood 59, $18-22$.

Sauer PJJ, Dane HJ \& Visser HKA (1984b) Longitudinal studies on metabolic rate, heat loss, and energy cost of growth in low birth weight infants. Pediatric Research 18, 254-259.

Stothers JK \& Warner RM (1979) Effect of feeding on neonatal oxygen consumption. Archives of Disease in Childhood 54, $415-420$.

Towers HM, Schulze KF, Ramakrishnan R \& Kashyap S (1999) Energy expended by low birth weight infants in the deposition of protein and fat. Pediatric Research 41, 584-589.

Wahlig M, Gatto CW, Boros SJ, Mammel MC, Mills MM \& Georgieff MK (1994) Metabolic response of preterm infants to variable degrees of respiratory illness. Journal of Pediatrics 124, 283-288.

Weir JB DeV (1949) New methods for calculating metabolic rate with special reference to protein metabolism. Journal of Physiology 109, 1-9.

Ziegler E, O'Donnel A \& Nelson S (1976) Body composition of the reference fetus. Growth 40, 329-341. 